\title{
Pemodelan Klaster Frekuensi Suara Bising Mesin Pesawat Menggunakan Metode Extended Kalman
} Filter

\author{
Neilcy Tjahjamooniarsih ${ }^{\# 1}$, Leonardus Sandy Ade Putra ${ }^{\# 2}$ \\ 1,2 Program Studi Teknik Elektro, Jurusan Teknik Elektro, Fakultas Teknik, Universitas Tanjungpura \\ Jl. Prof. Dr. H. Hadari Nawawi, Pontianak 78124 \\ ${ }^{1}$ neilcy.mooniarsih@ee.untan.ac.id \\ 2leonardusandydee.untan.ac.id
}

\begin{abstract}
Abstrak - Kebisingan adalah bunyi yang tidak diinginkan dari usaha atau kegiatan dalam tingkat dan waktu tertentu yang dapat menimbulkan gangguan kesehatan manusia dan kenyamanan lingkungan. Salah satunya kebisingan pada wilayah bandara yang terpancar dari gelombang suara mesin pesawat udara dan dapat mengganggu lingkungan. Menurut World Health Organization (WHO) suara bising sekeras 85 dB hanya dapat didengar secara terus menerus maksimal selama 8 jam perhari. Setiap peningkatan suara bising sebesar $3 \mathrm{~dB}$ maka suara bising bertambah dua kali lipat. Suara bising dapat menjadi salah satu penyebab gangguan pendengaran (Noise Induced Hearing Loss). Penelitian ini menyajikan perencanaan mekanisme identifikasi sistem yang mencakup perencanaan skema identifikasi, pembentukan pasangan data identifikasi, dan penurunan algoritme identifikasi. Metode Extended Kalman Filter digunakan dalam mekanisme identifikasi untuk menemukan model hubungan antara komponen dominan pembentuk suara bising dengan suara bising secara keseluruhan yang kemudian dilakukan validasi terhadap model tersebut. Pengujian terhadap model dilakukan menggunakan sinyal-sinyal hasil pengukuran yang tidak diikutsertakan selama proses identifikasi. Hasil dari penelitian ini diperoleh bahwa frekuensi noise saat pesawat tinggal landas berkisar antara $50 \mathrm{~Hz}-7000 \mathrm{~Hz}$ dengan model matematis spreaded continuous frequency.
\end{abstract}

Kata kunci- Identifikasi, Suara Bising, Model, Extended Kalman Filter, Bandara

\section{Pendahuluan}

\section{A. Latar Belakang}

Kebisingan adalah bunyi yang tidak diinginkan dari usaha atau kegiatan dalam tingkat dan waktu tertentu yang dapat menimbulkan gangguan kesehatan manusia dan kenyamanan lingkungan. Untuk daerah bandara, kawasan kebisingan adalah kawasan tertentu di sekitar bandara yang terpengaruh gelombang suara mesin pesawat udara dan yang dapat mengganggu lingkungan [1]-[2].
Baku tingkat kebisingan merupakan batas maksimal tingkat kebisingan yang diperbolehkan dibuang ke lingkungan dari usaha atau kegiatan sehingga tidak menimbulkan gangguan kesehatan manusia dan kenyamanan lingkungan. Aktivitas lepas landas pesawat menimbulkan suara bising yang bersumber dari gelombang suara mesin pesawat yang sangat mengganggu kenyamanan dan kesehatan pengguna bandara dan masyarakat sekitarnya [3]-[4].

Menurut WHO suara bising sekeras $85 \mathrm{~dB}$ hanya dapat didengar secara terus menerus maksimal selama 8 jam perhari. Untuk setiap peningkatan suara bising sebesar $3 \mathrm{~dB}$ maka suara bising bertambah dua kali lipat. Suara bising dapat menjadi salah satu penyebab gangguan pendengaran (Noise Induced Hearing Loss) [5]. Upaya pengendalian kebisingan yang diperlukan adalah dengan cara menekan intensitas gelombang suara bising sampai di bawah level baku tingkat kebisingan [6]-[7]. Pengendalian dapat dilakukan secara maksimal jika kebisingan tersebut dapat dimodelkan secara akurat. Penelitian ini bertujuan untuk mengetahui dan mengidentifikasi hubungan antara pembentukan suara bising terhadap suara bising secara keseluruhan melalui permodelan matematis.

\section{B. Urgensi Penelitian}

Kawasan bandara memberikan kebisingan suara yang signifikan dan kontinyu sehingga dapat menimbulkan gangguan kesehatan dan kenyamanan lingkungan sekitarnya. Untuk itu diperlukan upaya-upaya untuk menurunkan tingkat kebisingan suara hingga mencapai level di bawah level baku tingkat kebisingan yang telah ditetapkan oleh pemerintah. Keputusan Menteri Negara Lingkungan Hidup Nomor: KEP-48/MENLH/11/1996 tentang Baku Tingkat Kebisingan, dengan pertimbangan bahwa salah satu dampak dari usaha atau kegiatan yang dapat mengganggu kesehatan manusia, makhluk lain dan lingkungan adalah akibat tingkat kebisingan yang dihasilkan, menetapkan: Keputusan Menteri Negara Lingkungan Hidup tentang Baku Tingkat Kebisingan. 
Dalam keputusan ini yang dimaksud dengan kebisingan adalah bunyi yang tidak diinginkan dari usaha atau kegiatan dalam tingkat dan waktu tertentu yang dapat menimbulkan gangguan kesehatan manusia dan kenyamanan lingkungan; Tingkat kebisingan adalah ukuran energi bunyi yang dinyatakan dalam satuan Desibel disingkat dB; Baku tingkat kebisingan adalah batas maksimal tingkat kebisingan yang diperbolehkan dibuang ke lingkungan dari usaha atau kegiatan sehingga tidak menimbulkan gangguan kesehatan dan kenyamanan lingkungan [8]. Standar Nasional Indonesia (SNI 7231: 2009) menyatakan bahwa pengukuran kebisingan pada dasarnya meliputi pengukuran intensitas kebisingan, frekuensi dan dosis kebisingan [9]. Pada penelitian sebelumnya, pengujian terhadap penentuan suara bising dilakukan terhadap sumber suara dengan hanya melakukan pengukuran besaran $\mathrm{dB}$ yang diperoleh tanpa melakukan perhitungan matematis. Sehingga pada penelitian ini, bertujuan untuk melakukan identifikasi sumber suara penyebab dari suara bising secara keseluruhan yang diciptakan saat pesawat melakukan lepas landas dengan dimodelkan secara matematis.

\section{Metode PENELITIAN}

Penelitian ini mencakup beberapa tahapan, yaitu: pengumpulan data suara bising di area bandara, pengolahan data awal, pemrosesan sinyal identifikasi, perencanaan Identifikasi terhadap metode yang dipilih, perancangan perangkat lunak Identifikasi sinyal suara, proses identifikasi sistem, dan pengujian model matematis. Secara garis besar proses penelitian dapat diperlihatkan pada Gambar. 1.

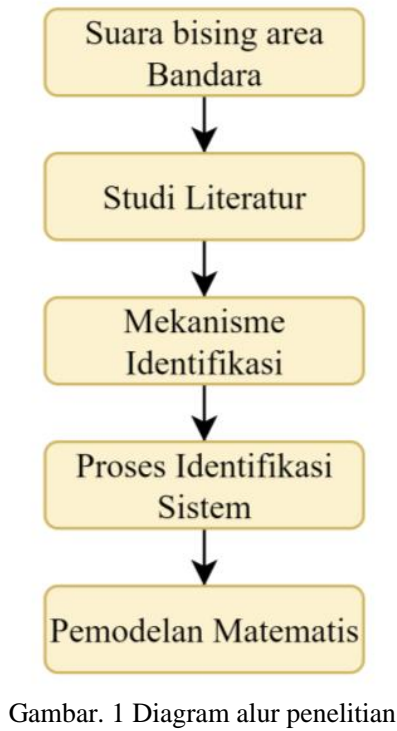

\section{A. Pengumpulan Data dan Pengolahan Data Pengukuran}

Lokasi pengumpulan data adalah di sekitar landasan pacu Bandara Supadio Pontianak. Variabel yang diukur adalah intensitas suara bising mesin pesawat pada saat lepas landas, dan amplitudo gelombang suara tersebut dalam domain waktu. Rekaman gelombang suara bising mesin pesawat pada saat lepas landas dalam domain waktu ditapis menggunakan Band Pass Filter (BPF) sehingga diperoleh gelombang suara mesin pesawat dalam rentang frekuensi audible. Untuk mendapatkan model matematis klaster frekuensi suara bising mesin pesawat diperlukan suatu mekanisme identifikasi [10].

Geometri pengukuran diperlihatkan pada Gambar. 2. Jarak titik pengukuran sejauh 200 meter jika dihitung dari titik D sampai pada titik dimana garis pengukuran memotong secara tegak lurus garis lintasan pesawat pada saat lepas landas. Jarak posisi start pesawat (A) dengan titik potong tersebut sejauh 450 meter.

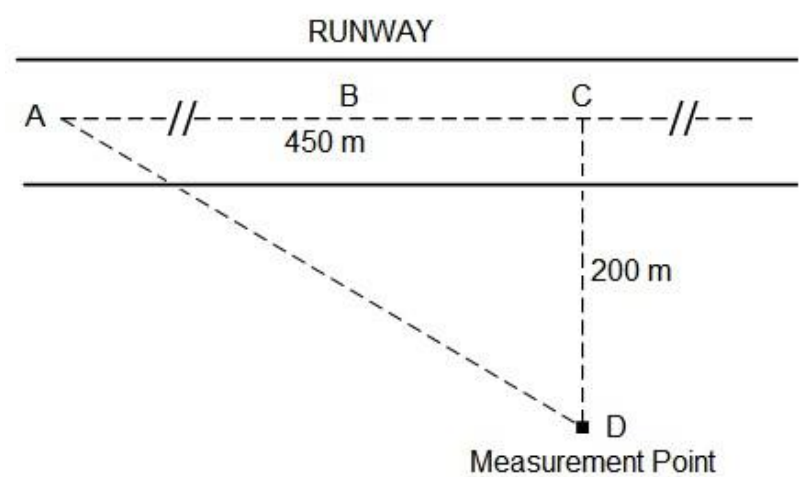

Gambar. 2 Geometri pengukuran data

Hasil pengukuran tersebut dapat diketahui berapa besar tingkat bising suara untuk setiap aktivitas lepas landas pesawat. Selain itu, suara bising juga direkam untuk melihat bentuk gelombang dan frekuensinya. Frekuensi yang akan diuji dapat diperlihatkan pada Tabel 1.

TABEL I

FREKUENSI SINYAL PEMBENTUK

\begin{tabular}{|c|c|}
\hline \multicolumn{2}{|c|}{ Klastering sinyal berdasarkan frekuensi pembentuk } \\
\hline Klaster I & Klaster II \\
\hline $20-250 \mathrm{~Hz}$ & $250-315 \mathrm{~Hz}$ \\
\hline $20-315 \mathrm{~Hz}$ & $315-500 \mathrm{~Hz}$ \\
\hline $20-315 \mathrm{~Hz}$ & $315-630 \mathrm{~Hz}$ \\
\hline $20-630 \mathrm{~Hz}$ & $630-1.250 \mathrm{~Hz}$ \\
\hline $20-1.250 \mathrm{~Hz}$ & $1.250-2.500 \mathrm{~Hz}$ \\
\hline $20-2.500 \mathrm{~Hz}$ & $2.500-5.000 \mathrm{~Hz}$ \\
\hline $20-5.000 \mathrm{~Hz}$ & $5.000-10.000 \mathrm{~Hz}$ \\
\hline $20-10.000 \mathrm{~Hz}$ & $10.000-10.000 \mathrm{~Hz}$ \\
\hline $50-250 \mathrm{~Hz}$ & $250-315 \mathrm{~Hz}$ \\
\hline $50-250 \mathrm{~Hz}$ & $250-20.000 \mathrm{~Hz}$ \\
\hline $50-500 \mathrm{~Hz}$ & $500-20.000 \mathrm{~Hz}$ \\
\hline
\end{tabular}

Dari representasi gelombang dalam ranah waktu, dilakukan segmentasi untuk menghitung besarnya tingkat suara bising pada titik-titik observasi, sehingga dapat dilihat berapa besar perubahan tingkat suara bising dihitung mulai dari titik awal start pesawat hingga pesawat melintasi titik dimana garis pengukuran memotong secara tegak lurus garis lintasan pesawat pada saat lepas landas. 


\section{B. Perencanaan Mekanisme Identifikasi}

Perencanaan mekanisme identifikasi sistem mencakup perencanaan skema identifikasi, pembentukan pasangan data identifikasi, penurunan algoritme identifikasi [11] [13].

1) Pembentukan pasangan data identifikasi: dimaksudkan untuk memperoleh pasangan data inputoutput (data I/O) yang akan digunakan dalam proses pembentukan model matematis klaster frekuensi suara bising mesin pesawat pada saat lepas landas. Pemrosesan ini bertujuan untuk merancang sebuah pemograman perangkat lunak dengan menggunakan software Matlab 2017 agar memperoleh model awal dalam proses Identifikasi frekuensi sinyal yang diperoleh pada tahap pengumpulan data. Sinyal akan melalui pemroses ekstraksi berdasarkan frekuensi gelombang yang diperoleh dan memisahkan bagian frekuensi yang tidak digunakan. Adapun tahapan dalam pemrosesan identifikasi sebagai berikut:

- Pembuatan perangkat lunak untuk menghitung komponen-komponen frekuensi sinyal menggunakan metode Discrete Fast Fourier Transform.

- Pembuatan perangkat lunak untuk menghitung Power Spectral Density sinyal dalam one-third octave band frequency.

- Pembuatan perangkat lunak untuk pengklasteran frekuensi sinyal.

- Melakukan ekstraksi frekuensi suara bising hasil rekaman. Proses ekstraksi berdasarkan frekuensi gelombang suara bising bertujuan untuk melihat rentang frekuensi komponen suara bising yang secara dominan mempengaruhi tingkat suara bising secara keseluruhan. Hasil rekaman akan dipisahkan sesuai dengan frekuensi gelombang bising yang diperoleh. Dari pemisahan tersebut dapat diperoleh frekuensi suara bising tertinggi yang dapat digunakan sebagai frekuensi bising dalam proses pemodelan.

- Pembentukan pasangan data I/O identifikasi.

2) Penurunan algoritme identifikasi Extended Kalman Filter: Koefisien-koefisien model matematis suara bising mesin pesawat diperoleh melalui mekanisme identifikasi secara adaptif menggunakan metode Extended Kalman Filter [14] (EKF) dengan tahapan pengerjaan sebagai berikut:

- Penurunan matematis algoritme EKF untuk identifikasi sistem

- Perancangan perangkat lunak algoritme EKF

- Verifikasi kode-kode program identifikasi.

\section{Proses Identifikasi Sistem}

Identifikasi dilakukan untuk mendapatkan model matematis klaster frekuensi suara bising mesin pesawat. Proses Identifikasi sistem adalah lanjutan dari proses klasifikasi yang dilakukan untuk memisahkan rekaman dengan frekuensi bising yang tinggi. Proses ini bertujuan untuk melakukan validasi terhadap frekuensi suara yang dianggap memiliki tingkat kebisingan yang lebih tinggi dari frekuensi lainnya. Setelah proses identifikasi, dilakukan validasi model hasil identifikasi [15].

\section{Pengujian Model}

Hasil dari frekuensi gelombang ekstraksi yang telah ditentukan dan di validasi, kemudian akan dilakukan proses pemodelan terhadap frekuensi tersebut. Pemodelan dirancang secara matematis sesuai dengan data yang telah diperoleh. Identifikasi suara perlu diuji terhadap model yang dirancang agar dapat dilakukan pembuktian ilmiah. Pengujian terhadap model dilakukan menggunakan sinyalsinyal hasil pengukuran yang tidak diikutsertakan selama proses Identifikasi. Pemodelan matematis diperlihatkan pada hasil pengujian dan pembahasan.

\section{HASIL PENGUJIAN DAN PEMBAHASAN}

\section{A. Penurunan Algoritme Identifikasi Extended Kalman Filter}

Dalam identifikasi sistem, sistem dan model diberikan sinyal uji yang sama. Tujuan identifikasi sistem adalah untuk menemukan model yang merepresentasikan sistem. Model yang diperoleh dari proses identifikasi, dianggap mewakili dinamika sistem.

Masukan model dirumuskan sebagai

$$
u_{i}(n)=X(n-l), \quad 0 \leq l \leq L
$$

$X(n-l)$ adalah sinyal uji pada saat $(n-l)$. $L$ menyatakan jumlah elemen dalam vektor masukan ke- $i$ dari model. $u_{i}(n)$ adalah vektor dengan $L$ dimensi.

Jika hidden layer model mempunyai neuron sebanyak $j$, matrik bobot masukan dan matriks bobot recurrent masingmasing dinyatakan sebagai $h_{i j l}$ dan $h_{j}$, maka neuron ke-j dirumuskan

$$
t_{j}(n)=\left(\sum_{i} \sum_{l=0}^{L} h_{i j l} u_{i}(n)\right)+h_{j} z_{j}(n-1), 0 \leq l \leq L
$$

$z_{j}(n-1)$ menyatakan jalur koneksi recurrent dari neuron ke-j di dalam hidden layer, dan nilai awal $z j(0)=0$. Tiaptiap neuron dalam hidden layer mempunyai fungsi alih nonlinear. Keluaran dari hidden layer pada saat $n$ dirumuskan sebagai

$$
Z_{j}(n)=f\left(t_{j}(n)\right)
$$

Sinyal keluaran ke-k dari model dirumuskan

$$
Z_{k}(n)=\sum_{j} h_{j k} Z_{j}(n)
$$

Selisih antara sinyal keluaran sistem dan sinyal keluaran model menyatakan kesalahan identifikasi sistem yang dirumuskan

$$
e_{k}(n)=y_{k}(n)-z_{k}(n)
$$

Komputasi balik struktur jaringan model untuk identifikasi sistem, diturunkan dengan aturan rantai. 
Gradien keluaran model terhadap bobot output layer dalam model dirumuskan

$$
\frac{\delta z_{k}(n)}{\delta h_{j k}(n)}=y_{j}(n)
$$

Gradien keluaran model terhadap bobot hidden layer dalam model dirumuskan

$$
\frac{\delta z_{k}(n)}{\delta h_{j k l}(n)}=\frac{\delta z_{k}(n)}{\delta z_{j}(n)} \frac{\delta z_{j}(n)}{\delta h_{i j l}(n)}, 0<l<L
$$

dengan $\frac{\delta z_{k}(n)}{\delta z_{j}(n)}=h_{j k}(n)$ dan $L$ menyatakan jumlah elemen sinyal masukan model.

Persamaan (5) ditulis

$$
\frac{\delta z_{k}(n)}{\delta z_{i j l}(n)}=h_{j k}(n) \frac{\delta z_{j}(n)}{\delta h_{i j l}(n)}
$$

dimana

$$
\frac{\delta z_{j}(n)}{\delta h_{i j l}(n)}=\frac{\delta z_{j}(n)}{\delta t_{j}(n)} \frac{\delta t_{j}(n)}{\delta h_{i j l}(n)} \quad \operatorname{dan} \frac{\delta z_{j}(n)}{\delta t_{j}(n)}=f^{\prime}\left(t_{j}(n)\right)
$$

Dengan memperhitungkan koneksi reccurent dalam hidden layer, maka gradien nilai neuron dalam hidden layer terhadap bobot hidden layer dirumuskan

$$
\frac{\delta t_{j}(n)}{\delta h_{i j l}(n)}=u_{i}(n)+\frac{\delta t_{j}(n)}{\delta z_{j}(n-1)} \frac{\delta z_{j}(n-1)}{\delta h_{i j l}(n)}
$$

dengan $\frac{\delta t_{j}(n)}{\delta z_{j}(n-1)}=h_{j}(n)$ maka Persamaan (8) ditulis

$$
\frac{\delta t_{j}(n)}{\delta h_{i j l}(n)}=u_{i}(n)+h_{j}(n) \frac{\delta z_{j}(n-1)}{\delta h_{i j l}(n)}
$$

dan pada saat $n=0$, nilai $\frac{\delta z_{j}(n-1)}{\delta h_{i j l}(n)}=0$.

$$
\frac{\delta z_{j}(n)}{\delta h_{i j l}(n)}=f^{\prime}\left(t_{j}(n)\right)\left(u_{i}(n)+h_{j}(n) \frac{\delta z_{j}(n-1)}{\delta h_{i j l}(n)}\right)
$$

Misalkan $\frac{\delta z_{j}(n)}{\delta h_{i j l}(n)}=R(n)$, maka gradien keluaran model terhadap boot hidden layer di dalam jaringan model dirumuskan kembali sebagai

$$
\frac{\delta z_{k}(n)}{\delta h_{i j l}(n)}=h_{j k}(n) R(n)
$$

Gradien keluaran model terhadap bobot koneksi recurrent dalam model dirumuskan

$$
\frac{\delta z_{k}(n)}{\delta h_{j}(n)}=\frac{\delta z_{k}(n)}{\delta z_{j}(n)} \frac{\delta z_{j}(n)}{\delta h_{j}(n)}
$$

dengan $\frac{\delta z_{k}(n)}{\delta z_{j}(n)}=h_{j k}(n)$, maka Persamaan (11) ditulis

$$
\frac{\delta z_{k}(n)}{\delta h_{j}(n)}=h_{j k}(n) \frac{\delta z_{j}(n)}{\delta h_{j}(n)}
$$

dimana

$$
\frac{\delta z_{j}(n)}{\delta h_{j}(n)}=\frac{\delta z_{j}(n)}{\delta t_{j}(n)} \frac{\delta t_{j}(n)}{\delta h_{j}(n)} \operatorname{dan} \frac{\delta z_{j}(n)}{\delta t_{j}(n)}=f^{\prime}\left(t_{j}(n)\right)
$$

Dengan memperhitungkan koneksi reccurent dalam hidden layer, maka gradien nilai neuron dalam hidden layer terhadap bobot koneksi jalur recurrent dirumuskan

$$
\frac{\delta t_{j}(n)}{\delta h_{j}(n)}=z_{j}(n)+\frac{\delta t_{j}(n)}{\delta z_{j}(n-1)} \frac{\delta z_{j}(n-1)}{\delta h_{j}(n)}
$$

dengan $\frac{\delta t_{j}(n)}{\delta z_{j}(n-1)}=h_{j}(n)$ maka Persamaan (13) dapat dituliskan sebagai

$$
\frac{\delta t_{j}(n)}{\delta h_{j}(n)}=z_{j}(n)+h_{j}(n) \frac{\delta z_{j}(n-1)}{\delta h_{j}(n)}
$$

dan pada saat $n=0, \frac{\delta z_{j}(n-1)}{\delta h_{j}(n)}=0$.

$$
\frac{\delta z_{j}(n)}{\delta h_{j}(n)}=f^{\prime}\left(t_{j}(n)\right)\left(z_{j}(n)+h_{j}(n) \frac{\delta z_{j}(n-1)}{\delta h_{j}(n)}\right)
$$

Misalkan $\frac{\delta z_{j}(n)}{\delta h_{j}(n)}=Q(n)$, maka gradien keluaran model terhadap bobot koneksi reccurent dalam model dirumuskan kembali sebagai

$$
\frac{\delta z_{j}(n)}{\delta h_{j}(n)}=h_{j k}(n) Q(n)
$$

Persamaan (5), (10), dan (15) disusun di dalam Persamaan (16)

$$
H(n)=\left[\begin{array}{l}
\frac{\delta z_{k}(n)}{\delta h_{j k}(n)} \\
\frac{\delta z_{k}(n)}{\delta h_{i j l}(n)} \\
\frac{\delta z_{k}(n)}{\delta h_{j}(n)}
\end{array}\right]
$$

Matrik gain Kalman model dirumuskan

$K(n)=\lambda^{-1} P(n) H(n)\left(1+\lambda^{-1} H(n)^{T} P(n) H(n)\right)^{-1}$

Matrik konvarian bobot model dirumuskan

$$
P(n+1)=\lambda^{-1}\left(P(n)-P(n) K(n) H(n)^{T}\right)
$$

Perbaharui semua bobot dalam model dirumuskan

$$
h(n+1)=h(n)-\mu K(n) e_{k}(n)
$$

Algoritme Extended Kalman Filter untuk identifikasi sistem dapat dijabarkan secara ringkas sebagai berikut:

- Pada saat ke- $n$, berikan sinyal uji yang sama ke jalur masukan sistem dan jalur masukan model.

- Hitung keluaran jaringan model menggunakan Persamaan (4.3).

- Keluaran jaringan model merupakan sinyal kendali yang akan dilewatkan ke sistem untuk menghasilkan sinyal anti derau.

- Hitung gradien keluaran model terhadap bobotbobot di dalam model.

- Hitung sinyal galat identifikasi, dengan cara menghitung selisih antara sinyal keluaran sistem dan sinyal keluaran model menggunakan Persamaan (4.4).

- $\quad$ Update bobot-bobot jaringan model. 
- $\quad$ Kembali ke langkah 1.

\section{B. Klastering Data I/O Identifikasi Sistem}

Pada setiap pengukuran selalu ada noise lingkungan yang tercampur ke dalam data hasil pengukuran. Untuk mendapatkan nilai data pengukuran yang sebenarnya, noise yang berasal dari lingkungan tersebut harus dipisahkan dari nominal data. Di dalam penelitian ini langkah pertama yang dilakukan untuk memisahkan noise tersebut adalah dengan melakukan klastering sinyal berdasarkan komponen frekuensi pembentuk sinyal tersebut. Dari klaster-klaster sinyal tersebut dihitung nilai korelasinya terhadap sinyal hasil pengukuran sebagaimana diperlihatkan oleh Gambar. 3 - Gambar. 35.
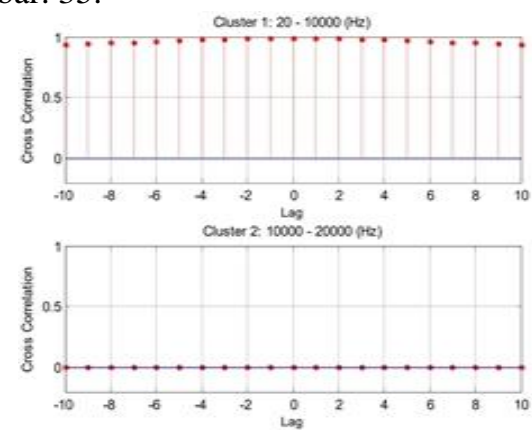

Gambar. 3 Korelasi sinyal untuk klaster frekuensi $20-10.000 \mathrm{~Hz}$ dan 10.000-20.000 Hz.

Gambar. 3 menunjukkan bahwa sinyal diklaster dalam rentang frekuensi $20-10.000 \mathrm{~Hz}$ dan $10.000-20.000 \mathrm{~Hz}$ Sinyal pada rentang frekuensi $10.000-20.000 \mathrm{~Hz}$ tidak berkorelasi dengan sinyal yang terukur, dengan Scatter plot dan representasi sinyal dalam domain waktu masingmasing diperlihatkan oleh Gambar. 4 dan Gambar. 5.

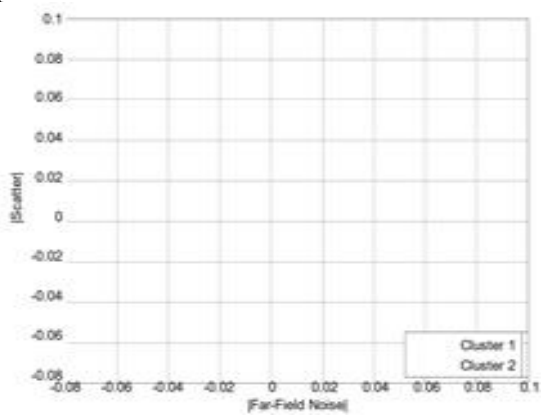

Gambar. 4 Scatter plot untuk klaster frekuensi 20-10.000 Hz dan 10.000$20.000 \mathrm{~Hz}$

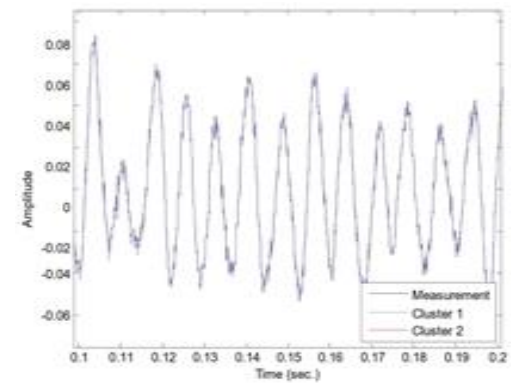

Gambar. 5 Representasi sinyal dalam domain waktu untuk klaster frekuensi $20-10.000 \mathrm{~Hz}$ dan $10.000-20.000 \mathrm{~Hz}$
Kemudian rentang pengklasteran diperkecil menjadi 20-10.000 Hz. Hasil perhitungan koefisien korelasi sinyal diperlihatkan pada Gambar. 6.

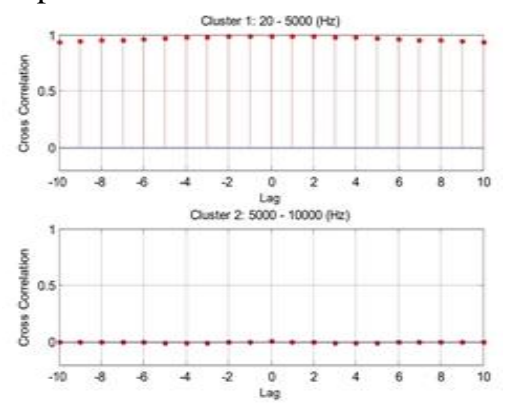

Gambar. 6 Korelasi sinyal untuk klaster frekuensi 20-5.000 Hz dan 5.000$10.000 \mathrm{~Hz}$

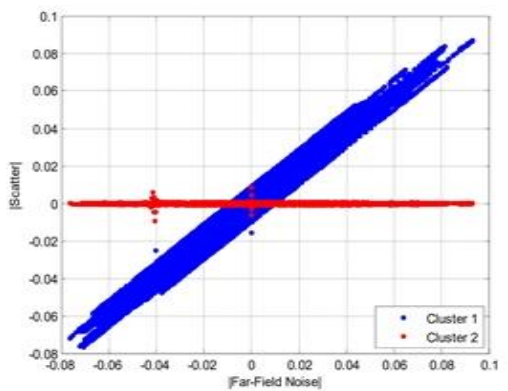

Gambar. 7 Scatter plot untuk klaster frekuensi 20-5.000 Hz dan 5.000$10.000 \mathrm{~Hz}$.

Gambar. 6 menunjukkan bahwa klaster sinyal dalam rentang frekuensi $5.000-10.000 \mathrm{~Hz}$ tidak berkorelasi dengan sinyal yang terukur, dengan scatter plot dan representasi sinyal dalam domain waktu masing-masing diperlihatkan oleh Gambar. 7 dan Gambar. 8.

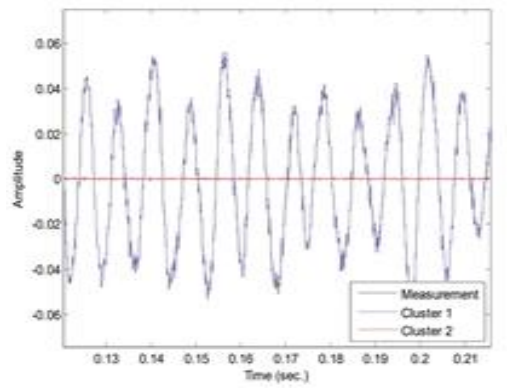

Gambar. 8 Representasi sinyal dalam domain waktu untuk klaster frekuensi $20-5.000 \mathrm{~Hz}$ dan $5.000-10.000 \mathrm{~Hz}$
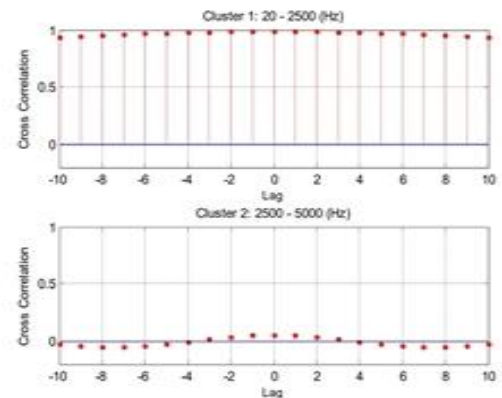

Gambar. 9 Korelasi sinyal untuk klaster frekuensi 20-2.500 Hz dan 2.500$5.000 \mathrm{~Hz}$ 


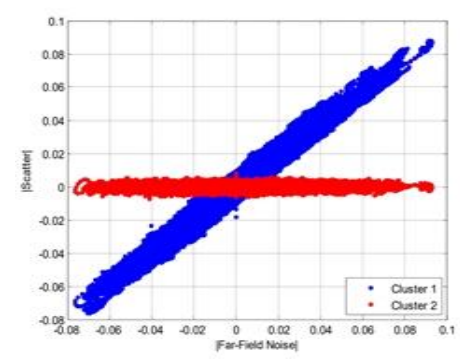

Gambar. 10 Scatter plot untuk klaster frekuensi $20-2.500 \mathrm{~Hz}$ dan 2.500$5.000 \mathrm{~Hz}$

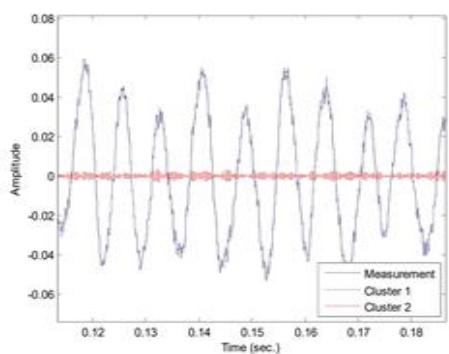

Gambar. 11 Representasi sinyal dalam domain waktu untuk klister frekuensi $20-2.500 \mathrm{~Hz}$ dan $2.500-5.000 \mathrm{~Hz}$

Investigasi terus dilakukan untuk memisahkan klaster sinyal yang tidak berkorelasi dengan sinyal yang terukur. Rentang pengklasteran kembali diperkecil menjadi 20$2.500 \mathrm{~Hz}$. Hasil perhitungan koefisien korelasi sinyal diperlihatkan pada Gambar. 11.

Gambar. 12 menunjukkan bahwa klaster sinyal dalam rentang frekuensi $1.250-2.500 \mathrm{~Hz}$ tidak berkorelasi dengan sinyal yang terukur, dengan scatter plot dan representasi sinyal dalam domain waktu masing-masing diperlihatkan oleh Gambar. 13 dan Gambar. 14.

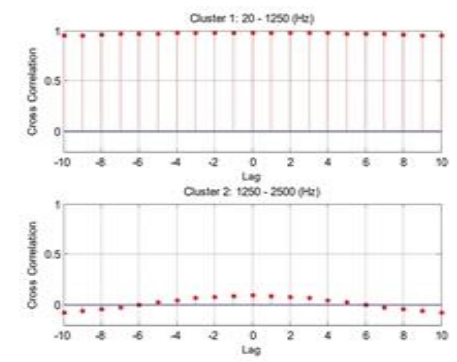

Gambar. 12 Korelasi sinyal untuk klaster frekuensi $20-1.250 \mathrm{~Hz}$ dan $1.250-2.500 \mathrm{~Hz}$

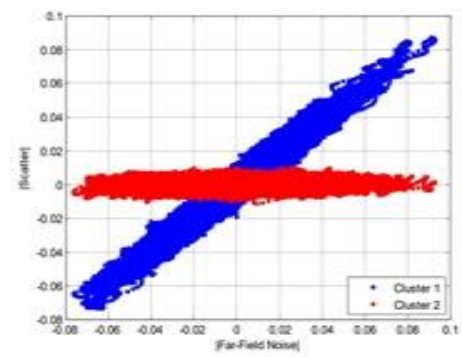

Gambar. 13 Scatter plot untuk klaster frekuensi $20-1.250 \mathrm{~Hz}$ dan 1.250 $2.500 \mathrm{~Hz}$

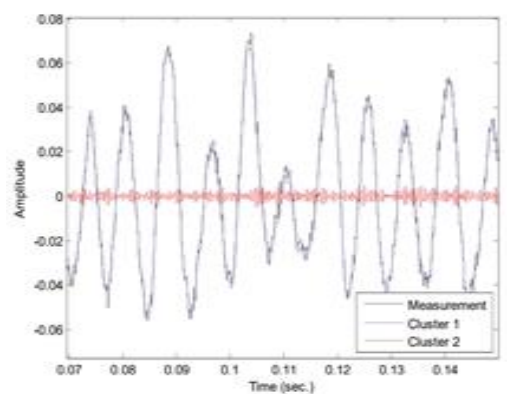

Gambar. 14 Representasi sinyal dalam domain waktu untuk klaster frekuensi $20-1.250 \mathrm{~Hz}$ dan $1.250-2.500 \mathrm{~Hz}$

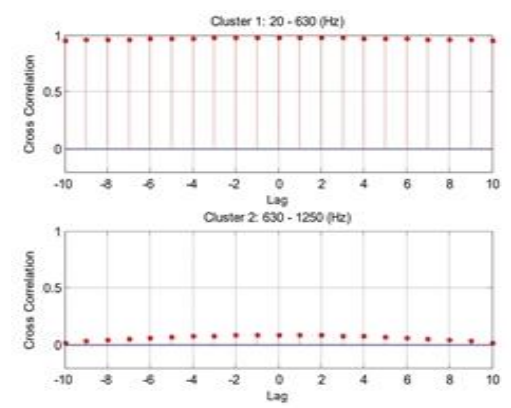

Gambar. 15 Korelasi sinyal untuk klaster frekuensi $20-630 \mathrm{~Hz}$ dan 630 $1.250 \mathrm{~Hz}$

Gambar. 15 menunjukkan bahwa klaster sinyal dalam rentang frekuensi $630-1.250 \mathrm{~Hz}$ tidak berkorelasi dengan sinyal yang terukur, dengan scatter plot dan representasi sinyal dalam domain waktu masing-masing diperlihatkan oleh Gambar. 16 dan Gambar. 17.

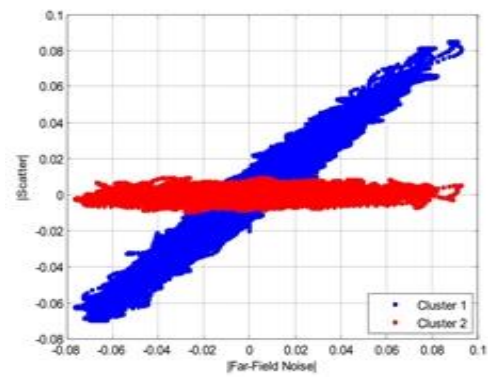

Gambar. 16 Scatter plot untuk klaster frekuensi 20-630 Hz dan 630-1.250 $\mathrm{Hz}$

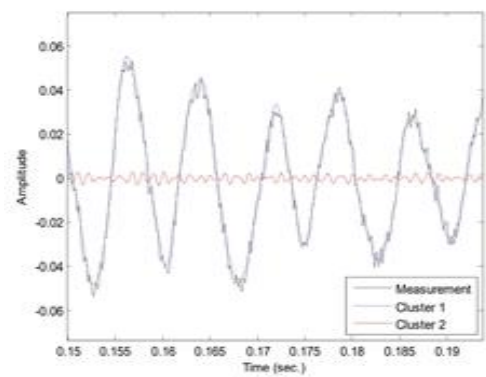

Gambar. 17 Representasi sinyal dalam domain waktu untuk klaster frekuensi $20-630 \mathrm{~Hz}$ dan $630-1.250 \mathrm{~Hz}$ 


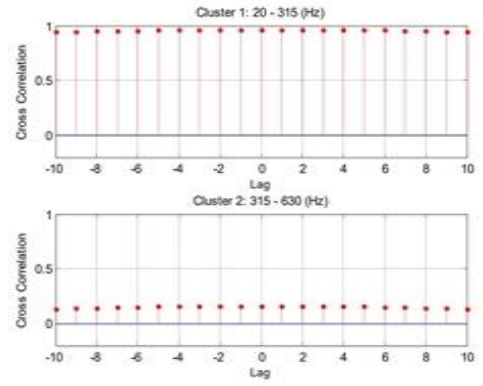

Gambar. 18 Korelasi sinyal untuk klaster frekuensi $20-315 \mathrm{~Hz}$ dan $315-$ $630 \mathrm{~Hz}$

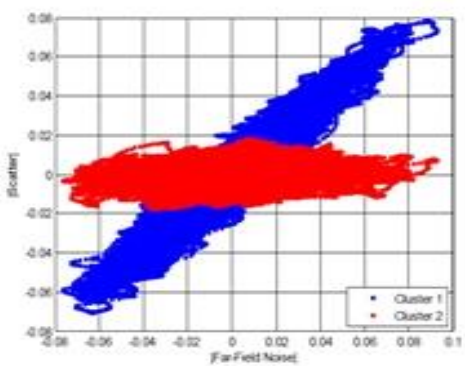

Gambar. 19 Scatter plot untuk klaster frekuensi 20-315 Hz dan 315-630 $\mathrm{Hz}$

Klastering sinyal dilanjutkan untuk rentang frekuensi 20-315 Hz dan 315-630 Hz. Sebaran nilai sinyal dan representasi sinyal dalam domain waktu masing-masing diperlihatkan oleh Gambar. 18 dan Gambar. 19. Gambar. 20 dan Gambar. 21 menunjukkan bahwa sinyal pada klaster kedua (dalam rentang frekuensi $315-630 \mathrm{~Hz}$ dan 315-500 $\mathrm{Hz})$ menunjukkan korelasi yang sangat lemah terhadap sinyal yang terukur.

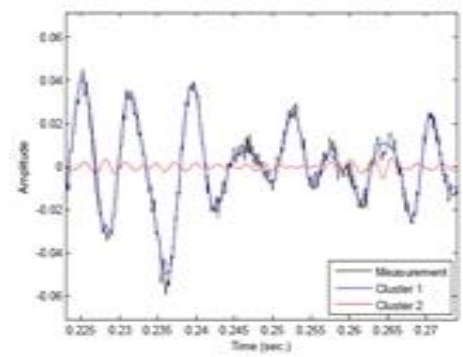

Gambar. 20 Representasi sinyal dalam domain waktu untuk klaster frekuensi $20-315 \mathrm{~Hz}$ dan $315-630 \mathrm{~Hz}$

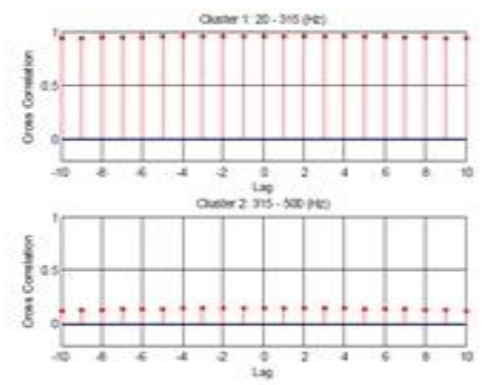

Gambar. 21 Korelasi sinyal untuk klaster frekuensi 20-315 Hz dan 315$500 \mathrm{~Hz}$

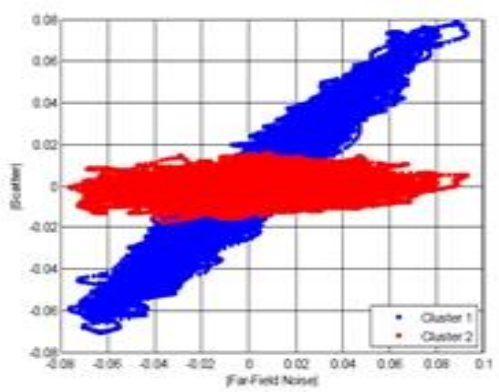

Gambar. 22 Scatter plot untuk klaster frekuensi $20-315 \mathrm{~Hz}$ dan 315-500 $\mathrm{Hz}$

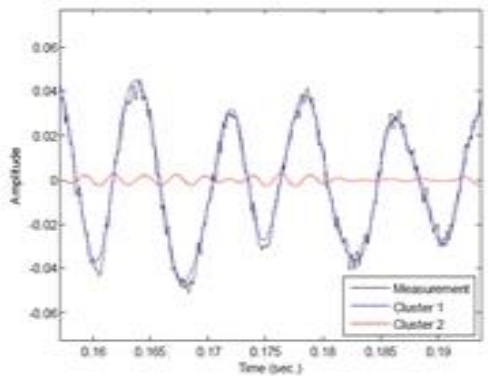

Gambar. 23 Representasi sinyal dalam domain waktu untuk klaster frekuensi $20-315 \mathrm{~Hz}$ dan $315-500 \mathrm{~Hz}$

Klaster sinyal dipersempit dalam rentang frekuensi 20$315 \mathrm{~Hz}$. Gambar. 24 menunjukkan bahwa klaster sinyal dalam rentang frekuensi $250-315 \mathrm{~Hz}$ mempunyai nilai korelasi yang sangat lemah terhadap sinyal terukut, dengan scatter plot dan representasi sinyal dalam domain waktu masing-masing diperlihatkan oleh Gambar. 25 dan Gambar. 26.

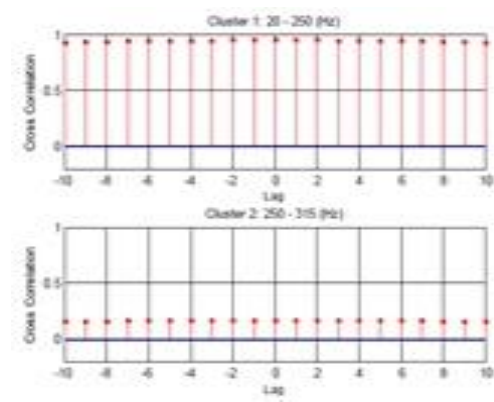

Gambar. 24 Korelasi sinyal untuk klaster frekuensi 20-250 Hz dan 250$315 \mathrm{~Hz}$

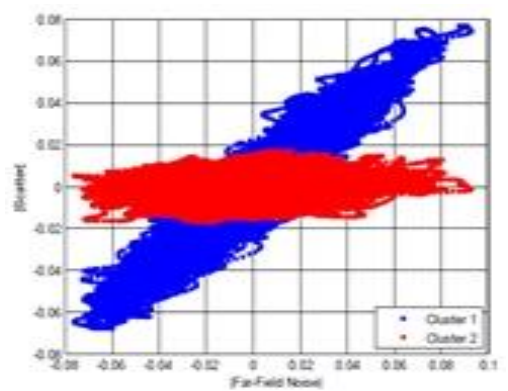

Gambar. 25 Scatter plot untuk klaster frekuensi 20-250 Hz dan 250-315 $\mathrm{Hz}$ 


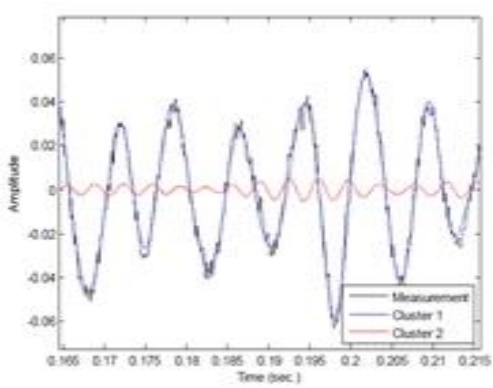

Gambar. 26 Representasi sinyal dalam domain waktu untuk klaster frekuensi $20-250 \mathrm{~Hz}$ dan $250-315 \mathrm{~Hz}$
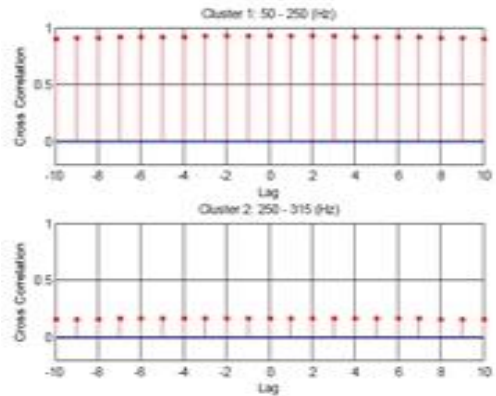

Gambar. 27 Korelasi sinyal untuk klaster frekuensi 50-250 Hz dan 250$315 \mathrm{~Hz}$

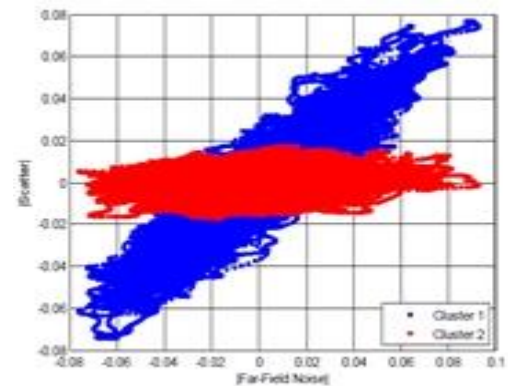

Gambar. 28 Scatter plot untuk klaster frekuensi 50-250 Hz dan 250-315 $\mathrm{Hz}$

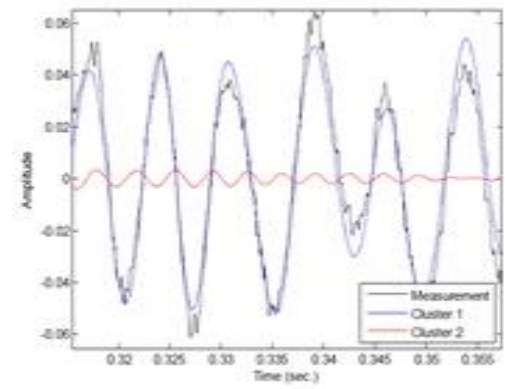

Gambar. 29 Representasi sinyal dalam domain waktu untuk klaster frekuensi $50-250 \mathrm{~Hz}$ dan $250-315 \mathrm{~Hz}$
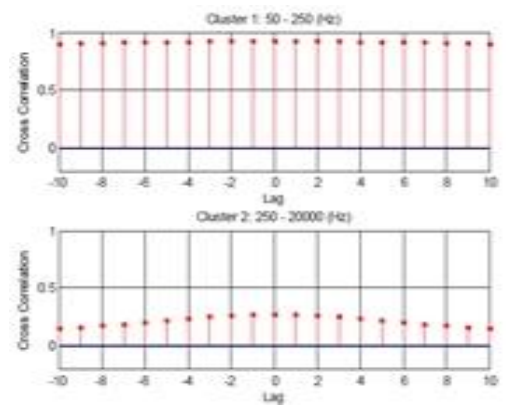

Gambar. 30 Korelasi sinyal untuk klaster frekuensi 50-250 Hz dan 250$20.000 \mathrm{~Hz}$

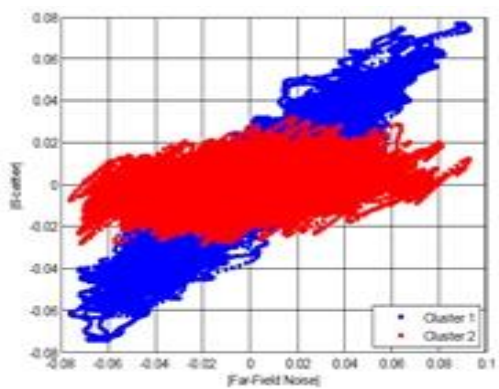

Gambar. 31 Scatter plot untuk klaster frekuensi 50-250 Hz dan 250-20.000 $\mathrm{Hz}$

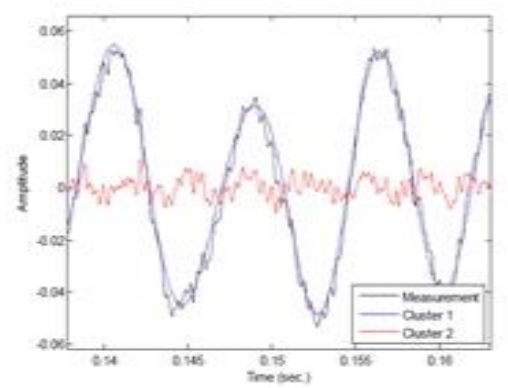

Gambar. 32 Representasi sinyal dalam domain waktu untuk klaster frekuensi $50-250 \mathrm{~Hz}$ dan $250-20.000 \mathrm{~Hz}$
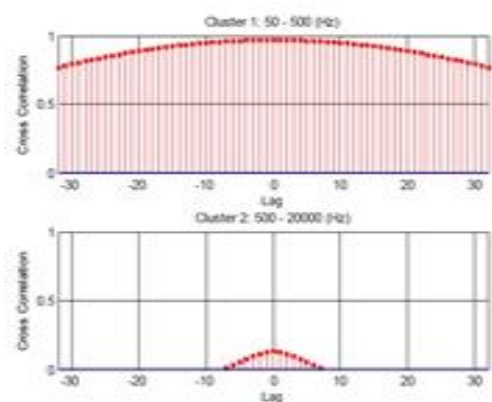

Gambar. 33 Korelasi sinyal untuk klaster frekuensi 50-500 Hz dan 500 $20.000 \mathrm{~Hz}$ 


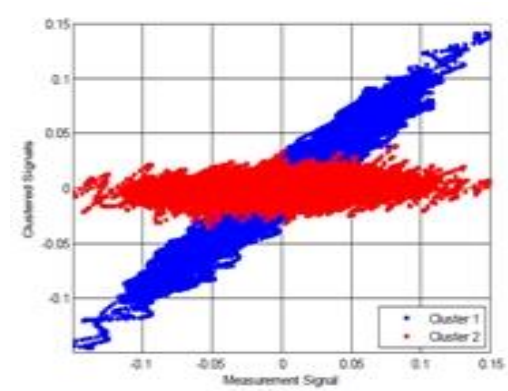

Gambar. 34 Scatter plot untuk klaster frekuensi 50-500 Hz dan 500-20.000 $\mathrm{Hz}$

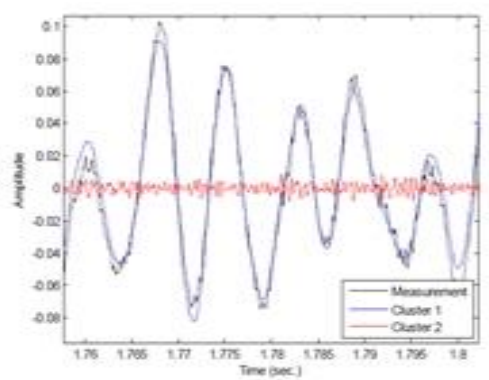

Gambar. 35 Representasi sinyal dalam domain waktu untuk klaster frekuensi $50-500 \mathrm{~Hz}$ dan 500-20.000 Hz

\section{Analisis Korelasi}

Analisis korelasi secara kuantitatif digunakan untuk melihat hubungan dan perubahan sinyal hasil pengukuran terhadap elemen-elemen pembentuk sinyal tersebut. Di dalam penelitian ini yang menjadi fokus perhatian adalah sinyal noise dari aktivitas tinggal landas pesawat. Gambar. 36 menunjukkan koefisien korelasi sinyal noise hasil pengukuran terhadap take off noise dan noise lingkungan.
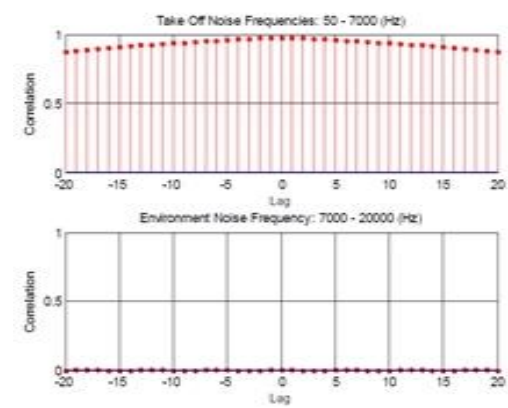

Gambar. 36 Korelasi sinyal untuk klaster frekuensi $20-7.000 \mathrm{~Hz}$ dan 7000$20000 \mathrm{~Hz}$

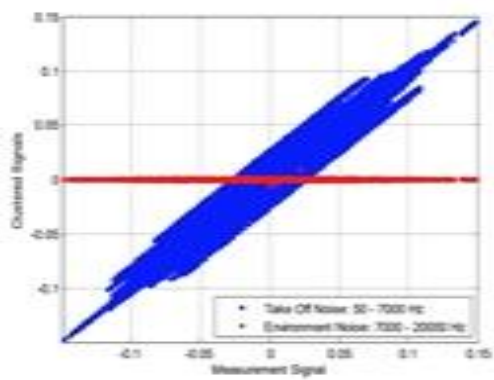

Gambar. 37 Scatter plot sinyal untuk klaster frekuensi $50-7.000 \mathrm{~Hz}$ dan $7000-20000 \mathrm{~Hz}$
Take off noise (50-7000 Hz) mempunyai koefisien korelasi sebesar 0,95 dan noise lingkungan (7000-20000 $\mathrm{Hz}$ ) mempunyai koefisien korelasi 0,05. Gambar. 37 menunjukkan sebaran nilai sinyal saat lepas landar (50$7000 \mathrm{~Hz})$ noise lingkungan (7000-20000 Hz). Dari rentang frekuensi $50-7.000 \mathrm{~Hz}$ dilakukan pengklasteran menjadi kembali menjadi beberapa klaster yaitu: $50-500 \mathrm{~Hz}, 500$ - $2.500 \mathrm{~Hz}$, dan 2.500 - $7.000 \mathrm{~Hz}$. Gambar. 38 menunjukkan koefisien korelasi sinyal untuk klaster frekuensi 50-500 Hz sebesar 0,98. Sedangkan untuk klaster frekuensi 500 - $2500 \mathrm{~Hz}$ dan 2500 - 7000 masing-masing sebesar 0,12 dan 0,05 .

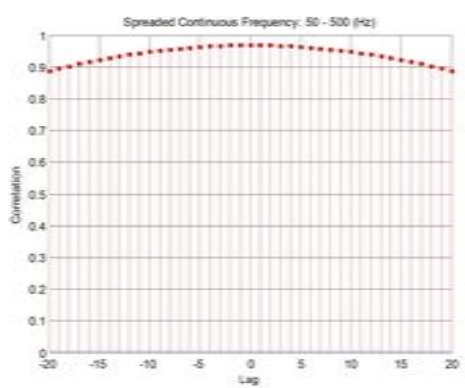

(a)

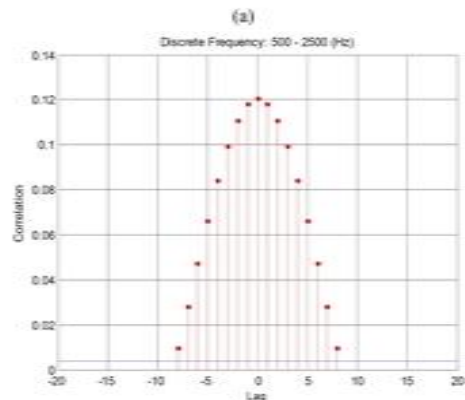

(b)

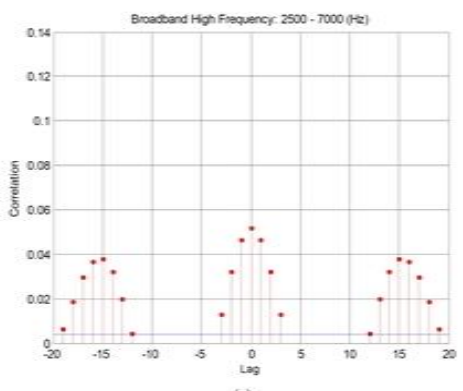

Gambar. 38 Korelasi sinyal untuk klaster frekuensi: (a) $50-500 \mathrm{~Hz}$, (b) $500-2.500 \mathrm{~Hz}$, (c) $2.500-7.000 \mathrm{~Hz}$

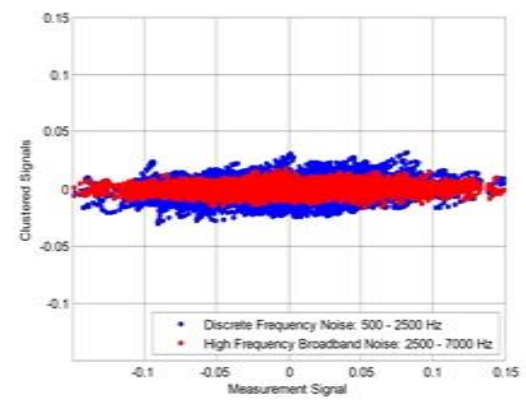

Gambar. 39 Scatter plot sinyal untuk klaster frekuensi 500-2.500 Hz dan 2.500-7000 Hz 


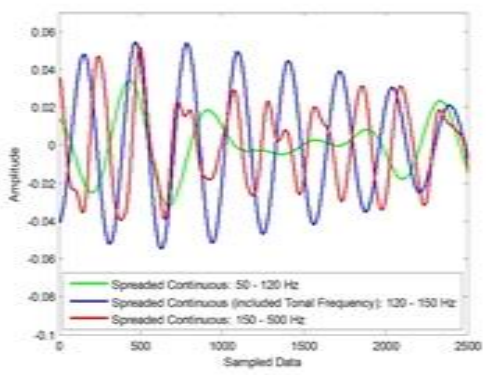

Gambar. 40 Representasi sinyal dalam domain waktu untuk klaster frekuensi antara $50-500 \mathrm{~Hz}$

Karena tonal frekuensi noise berada di dalam rentang spreaded continuous frequency noise maka kita lakukan pengklasteran kembali dalam rentang antara $50-500 \mathrm{~Hz}$ yaitu: klaster $50-120 \mathrm{~Hz}, 120-150 \mathrm{~Hz}$, dan $150-500 \mathrm{~Hz}$.

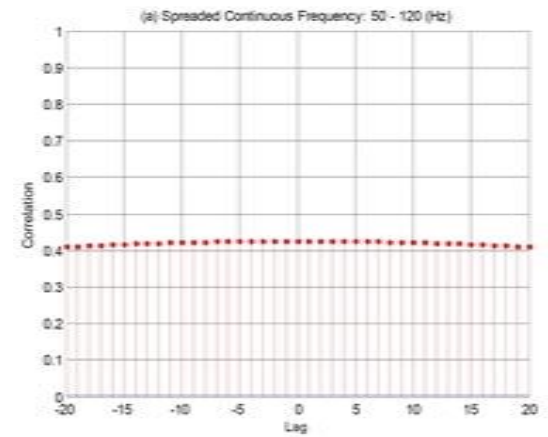

(a)

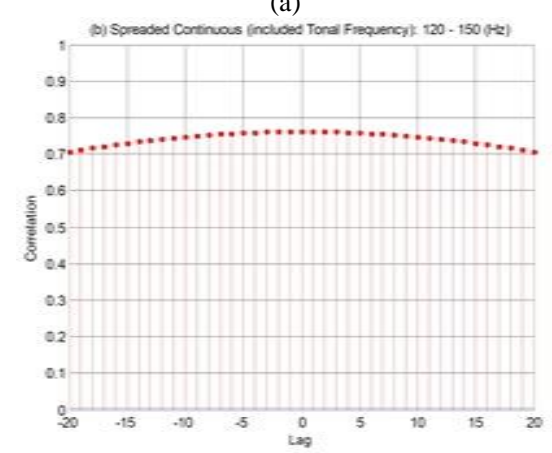

(b)

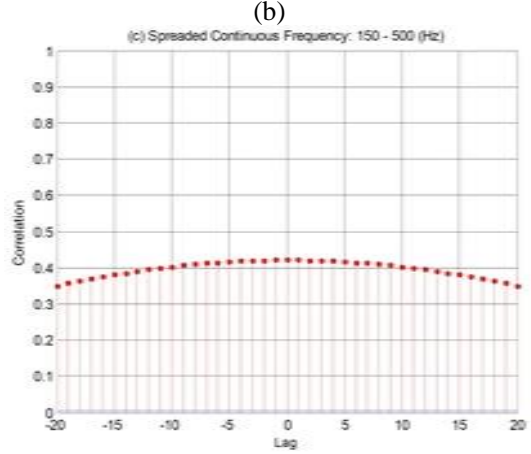

(c)

Gambar. 41 Korelasi sinyal untuk klaster frekuensi: (a) 50-120 Hz, (b) $120-150 \mathrm{~Hz}$, (c) $150-500 \mathrm{~Hz}$

Sebagaimana diperlihatkan oleh Gambar. 41, dari hasil perhitungan koefisien korelasi diperoleh nilai 0,42 untuk rentang frekuensi $50-120 \mathrm{~Hz}, 0,77$ untuk $120-150 \mathrm{~Hz}$, dan 0,42 untuk $150-500 \mathrm{~Hz}$. Koefisien korelasi terbesar adalah pada rentang frekuensi $120-150 \mathrm{~Hz}$ sehingga patut diduga bahwa tonal frekuensi noise berada di sekitar rentang tersebut.

\section{Hasil Proses Identifikasi Sistem}

Dalam identifikasi sistem, sistem dan model diberikan sinyal uji yang sama. Tujuan identifikasi sistem adalah untuk menemukan model yang merepresentasikan sistem. Model yang diperoleh dari proses identifikasi, dianggap mewakili dinamika sistem.

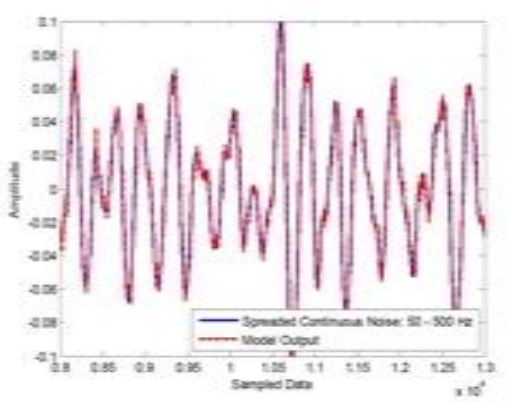

Gambar. 42 Perbandingan antara spreaded continuous frequency noise dan keluaran model

Sedangkan untuk diskrete frekuensi noise (500 - 2500 $\mathrm{Hz})$ dan high frequency broadband noise $(2500-7000 \mathrm{~Hz})$ masing-masing sebesar 0,12 dan 0,05 dan identifikasi terhadap klaster-klaster noise tersebut, diperoleh aproksimasi model matematis Spreaded Continuous Frequency, yang diperlihatkan pada Gambar. 43.

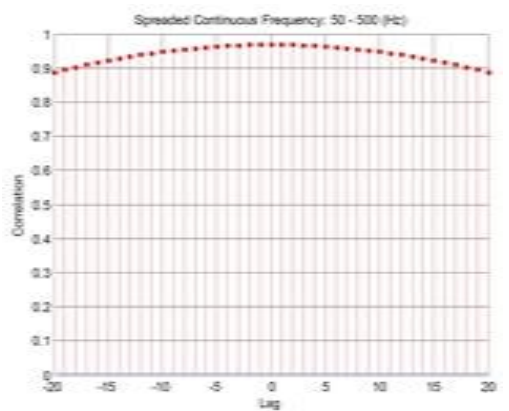

(a)

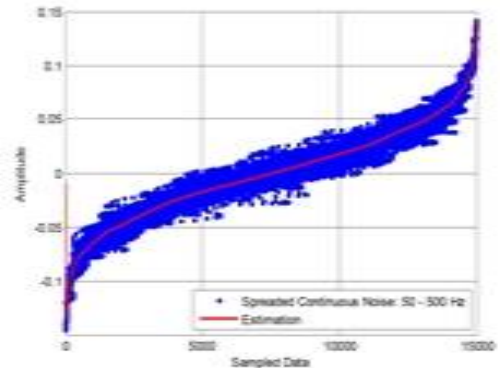

(b)

Gambar. 43 Diskrete frequency noise dan Spreaded Continuous Frequency $50-500 \mathrm{~Hz}$. 
Tonal frekuensi noise berada di dalam rentang spreaded continuous frequency noise. Hasil identifikasi terhadap klaster-klaster noise tersebut, diperoleh aproksimasi model matematis Spreaded Continuous Frequency

$$
\begin{aligned}
& \quad y=\frac{2}{1+\exp \left(-2 w_{i} x_{i}\right)}-1\left( \pm 6,3879 \times 10^{-5}\right) \\
& \qquad i=1,2,3, \ldots, 16 \\
& \text { dimana } \\
& \text { dan } \begin{array}{l}
\text { w } \\
\text { 0.062 } 1 ; 0.0620 ; 0.0618 ; 0.0616 ; 0.0614 ; \\
0.0604 ; 0.0610 ; 0.0609 ; 0.0607 ; 0.0605 ; \\
0.0596]
\end{array}
\end{aligned}
$$

\section{KESIMPULAN}

Suara bising yang dihasilkan oleh pesawat saat proses tinggal landas merupakan salah satu suara yang dapat mengganggu bagi penduduk sekitar bandara. Hasil pengujian menyatakan bahwa nilai koefisien korelasi yang diperoleh sebesar 0,95. Sehingga dapat disimpulkan bahwa rentang frekuensi noise saat pesawat tinggal landas adalah berkisar antara $50 \mathrm{~Hz}-7000 \mathrm{~Hz}$.

Berdasarkan koefisien korelasi yang diperoleh membuktikan bahwa spreaded continuous frequency noise merupakan frekuensi dominan dari take off noise secara keseluruhan. Hasil identifikasi terhadap klaster-klaster noise tersebut, diperoleh aproksimasi model matematis Spreaded Continuous Frequency.

Penelitian ini dapat menjadi dasar kajian dalam melakukan upaya untuk meredam suara bising keluar dari area bandara yang mengganggu penduduk sekitar maupun efek dari kesehatan dari pendengaran manusia dalam frekuensi tinggi secara terus menerus.

\section{REFERENSI}

[1] Antonio J. Torija, Rod H. Self, Ian H. Flindell, "Airport noise modelling for strategic environmental impact assessment of aviation," in Elsevier, Applied Acoustics, Volume 132, March 2018, Pages 49-57.

[2] R. Geise, A. Weiss, and B. Neubauer, "Modulating features of field measurements with a UAV at millimeter wave frequencies," 2018 IEEE Conf. Antenna Meas. Appl. CAMA 2018, pp. 1-4, 2018, doi: 10.1109/CAMA.2018.8530475.
[3] A. Rodríguez-Díaz, B. Adenso-Díaz, P.L. González-Torre, A review of the impact of noise restrictions at airports, Elsevier, Transportation Research Part D: Transport and Environment, Volume 50, January 2017, Pages 144-153.

[4] Les Frair, "Airport noise modelling and aircraft scheduling so as to minimize community annoyance," Elsevier, Applied Mathematical Modelling, Volume 8, Issue 4, August 1984, Pages 271-281.

[5] N. Rizqi Septiana, E. Widowati Kesehatan dan Keselamatan Kerja, J. Ilmu Kesehatan Masyarakat, and F. Ilmu KeolahragaanUniversitas Negeri Semarang, "73 Higeia 1 (1) (2017) Gangguan Pendengaran Akibat Bising,” vol. 1, no. 1, pp. 73-82, 2017.

[6] P. Andarani, T. Istirokhatun, G. Suhariani, and W. Budiawan, "Model simulations of noise pollution due to departures and approaches of passenger aircrafts around Achmad Yani airport Semarang - Indonesia," 2016 2nd Int. Conf. Ind. Mech. Electr. Chem. Eng. ICIMECE 2016, pp. 147-151, 2017, doi: 10.1109/ICIMECE.2016.7910442.

[7] J. Naganawa, K. Morioka, J. Honda, N. Kanada, N. Yonemoto, and Y. Sumiya, "Antenna configuration mitigating ground reflection fading on airport surface for AeroMACS," 2017 IEEE Conf. Antenna Meas. Appl. CAMA 2017, vol. 2018-January, pp. 91-94, 2018, doi: 10.1109/CAMA.2017.8273487.

[8] M. Arntzen, D.G. Simons, "Modeling and synthesis of aircraft flyover noise,", International Journal of Aeroacoustics, volume 13, no. 5-6, 2014, pp 449-462.

[9] Bambang Riyantoet. al. (2008): Active Noise Control in Free Space using Recurrent Neural Networks with EKF Algorithm, Journal of Control and Intelligent Systems, Acta Press, 36 (3), 267-276.

[10] Ku, C. C., Lee, K. Y. (1995): Diagonal Recurrent Neural Network for Dynamics Systems Control, IEEE Trans. on Neural Networks, 6 (1), 144-156.

[11] Kuo, S. M., Morgan, D. R. (1996): Active Noise Control systems: Algorithms and DSP implementations, John Wiley \& Sons, Inc., New York.

[12] Y. Xu, K. Xu, J. Wan, Z. Xiong, and Y. Li, "Research on Particle Filter Tracking Method Based on Kalman Filter," Proc. 2018 2nd IEEE Adv. Inf. Manag. Commun. Electron. Autom. Control Conf. IMCEC 2018, no. Imcec, pp. 1564-1568, 2018, doi: 10.1109/IMCEC.2018.8469578.

[13] C. Yan, J. Dong, G. Lu, D. Zhang, and Y. Qi, “An adaptive algorithm based on levenberg-marquardt method and two-factor for iterative extended Kalman filter," 2017 3rd IEEE Int. Conf. Comput. Commun. ICCC 2017, vol. 2018-January, no. 1, pp. 1559-1563, 2018, doi: 10.1109/CompComm.2017.8322802.

[14] M. Safitri, A. Cahyadi, E. Firmansyah, and J. Grafika, "Estimas Posisi UAV dengan Kalman Filter," no. September, pp. 240-245, 2015.

[15] R. R. Yacoub, "Analisis Gelombang Suara Mesin Pesawat Saat Lepas Landas di Bandar Udara Internasional Supadio Pontianak," JTEV (Jurnal Tek. Elektro dan Vokasional), vol. 5, no. 1.1, pp. 115119,2019 